Instructions for authors, subscriptions and further details:

http://mcs.hipatiapress.com

\title{
Portrayals of Caring Masculinities in Fiction Film: the Male Caregiver in Still Mine, Intouchables and Nebraska
}

Núria Araüna, Iolanda Tortajada \& Cilia Willem ${ }^{1}$

1) Universitat Rovira i Virgili, Spain

Date of publication: February $21^{\text {st }}, 2018$

Edition period: June 2018 - October 2018

To cite this article: Araüna, N.; Tortajada, I. \& Willem, C. (2018). Portrayals of Caring Masculinities in Fiction Film: the Male Caregiver in Still Mine, Intouchables and Nebraska. Masculinities and Social Change,7(1),82-102. doi: 10.17583/MCS.2018.2749

To link this article: http://doi.org/10.17583/MCS.2018.2749

\section{PLEASE SCROLL DOWN FOR ARTICLE}

The terms and conditions of use are related to the Open Journal System and to Creative Commons Attribution License (CC-BY). 
MCS - Masculinities and Social Change Vol. 7 No. 1 February 2018

pp. $82-102$

\section{Portrayals of Caring Masculinities in Fiction Film: The Male Caregiver in} Still Mine, Intouchables and $\mathrm{Ne}$ braska ${ }^{1}$

Núria Araüna

Universitat Rovira i Virgili

Cilia Willem

Universitat Rovira $i$ Virgili
Iolanda Tortajada

Universitat Rovira i Virgili

\section{Abstract}

This article analyzes the male caregiving characters Driss in Intouchables (2011), Craig in Still Mine (2012) and David in Nebraska (2013) in terms of hegemonic masculinity and its variations (Connell, 1990; Connell \& Messerschmidt, 2005). Caregiving is a complex social situation normally assumed within kinship relationships, and traditionally attributed to women. We briefly review feminist analysis of caregiving since the 1970s (Fine \& Glendinning, 2005), and use critical studies on men and masculinities to show that the uptaking of caring tasks by men would and is contributing to equality between women and men (Elliott, 2015). We have looked at the portrayal of the male caregivers in these films, and if and how they challenge hegemonic masculinity in terms of positive experiences. Our findings show that despite the tension men experience between giving in to and challenging patriarchal privilege of a carefree life, strategies such as humour, complicity, outdoor action and a general concern for the dignity of the care-receiver can be identified as some of these features of (imagined) caring masculinities and open new spaces for defining care as a gender neutral activity.

Keywords: care, hegemonic masculinity, feminist care theory, caring masculinities, film analysis 
MCS - Masculinities and Social Change Vol. 7 No. 1 February 2018 pp. $82-102$

\section{Representaciones de Masculinidades Cuidado- ras en las Películas de Ficción: El Hombre Cuidador en Still Mine, Intouchables y Ne- braska}

Núria Araüna

Universitat Rovira $i$ Virgili

Cilia Willem

Universitat Rovira $i$ Virgili
Iolanda Tortajada

Universitat Rovira i Virgili

\section{Resumen}

Este artículo se centra en la representación de los hombres cuidadores en el cine contemporáneo. Se analizan los personajes de Driss en el filme Intouchables (2011), Craig en Still Mine (2012) y David en Nebraska (2013). Los tres se estudian en relación a los rasgos que presentan de masculinidad hegemónica (Connell, 1990; Connell \& Messerschmidt, 2005). La prestación de cuidados es una situación social compleja tradicionalmente asignada a las mujeres. A lo largo del artículo, se resume la teoría feminista acerca de los cuidados (Fine\& y Glendinning, 2005) y se presentan estudios críticos sobre las masculinidades para demostrar que la asunción de responsabilidades en relación al cuidado por parte de los hombres puede contribuir a la igualdad entre mujeres y hombres (Elliott, 2015). En el plano de la representación, se analiza la caracterización de los cuidadores masculinos en estas películas y cómo desafían a la masculinidad hegemónica a través de las experiencias positivas en relación al cuidado. Nuestros resultados muestran que, a pesar de la tensión que los personajes masculinos experimentan entre ceder o bien desafiar al privilegio patriarcal de una vida libre de preocupaciones en torno al cuidado, se abren nuevos espacios para definir el cuidado como una actividad neutral en cuanto al género. Estas (imaginadas) masculinidades cuidadoras aparecen vinculadas a una figura competente que lleva a cabo su tarea usando estrategias como el humor, la complicidad y la acción al aire libre, retornado así la dignidad a la persona cuidada.

Palabras clave: cuidados, masculinidad hegemónica, teoría feminista de los cuidados, masculinidades cuidadoras, análisis fílmico 
aregiving is a complex social situation comprising several activities aimed at the well-being of others, normally assumed within kinship relationships, and traditionally attributed to women (Fine \& Glendinning, 2005). Since the 1970s, feminist analysis of caregiving has sought to deconstruct the notion of the feminization of care work within patriarchal cultures. Likewise, critical studies on men and masculinities have emphasized that the uptaking of caring tasks by men would and is contributing dramatically to equality between women and men (see for example Elliott, 2015). However, the social construction of caring masculinities is still hindered by many factors, such as economical, political and cultural barriers (Comas d'Argemir, 2016). One of those barriers, which we will look at in this article, is the construction of care and caregiving in cultural products such as fiction films. To start with, portrayals of male caregivers are not very frequent in mainstream film production: with the exception of caregiving in their quality as fathers - images of dads taking care of their babies and children have been profusely exploited in fiction film as either 'extraordinary', 'cute' or 'funny' — men are generally absent from the big screen when it comes to taking care of for example an elderly parent, a spouse or a disabled person. This article brings into focus three recent films that do portray men as caregivers: in Intouchables (directed by Olivier Nakache and Eric Toledano, 2011) Driss is hired to take care of a tetraplegic aristocrat; Still Mine (directed by Michael McGowan, 2012) pictures Craig taking care of his wife, who suffers Alzheimer's disease, and starts building a house for the two of them; and in Nebraska (directed by Alexander Payne, 2013) David joins his father with dementia behaviours on a road trip. Despite - or thanks to - the fact that the films are produced in divergent production circumstances, set in different countries and contrasting scenarios, the construction of the caring masculinities of Driss, Craig and David give us insight into the debate on how men in Western societies can be involved in the struggle for gender equality, as they show the potential of (imagined) masculine practices of care.

Our main interest lies in looking at these fictional caring masculinities, to which models of masculinity they respond, what kind of relationship the male caregivers have with their care-receivers, and in what ways male caregivers challenge (or not) hegemonic masculinity. 


\section{Hegemonic Masculinity and its Variations}

The concept of hegemonic masculinity, consolidated by Connell as part of her gender order theory in the late 1980s, transcends the notion of social role when explaining how gender is culturally constructed. Masculinity is both a personal feature and a manifestation of social structure, the first and the latter interacting with each other. Based on this premise, we understand hegemonic masculinity as a form of masculine character that has been culturally idealized, a pattern of masculinity celebrated and exalted by role models (Carrigan, Connell \& Lee, 1985; Connell, 1990). A particular model of masculinity is thus constructed in the field of common sense, defining what it means to be a man (Hanke, 1998) and turning the "normative" into the "normal" (Kimmel, 1993). The main patterns of contemporary hegemonic masculinity evolve around the subordination of women, the marginalization of gay men, and an association of masculinity with being tough and competitive (Connell, 1990). The set of idealized standards for men includes courage, strength, emotional stability and rationality, as well as the continuous preoccupation with proving gender to others (Coston \& Kimmel, 2012). The exaltation of hegemonic masculinity is the way in which the gender order is stabilized (Connell, 1990) and the reason why gender operates as a mechanism of marginalization (Coston \& Kimmel, 2012).

Hegemony, then, is the ability of a particular model of masculinity to impose its definitions and norms on other masculinities on the one hand, and of men occupying key positions of power in order to reproduce the relations of domination that allow them to maintain their privileges, on the other (Carrigan, Connell \& Lee, 1985). However, despite the predominance of hegemonic masculinity, we must not forget that the patterns described so far are historically situated and do not necessarily respond to a unitary role (Connell, 1990, 1996): the collective practices that construct masculinity are multiple, contradictory and change over time (Connell \& Messerschmidt, 2005), so that masculinities are heterogeneous (Coston \& Kimmel, 2012).

Connell and Messerschmidt (2005) revisited their own hegemonic masculinity model by suggesting a reformulation of some concepts, among which the social embodiment of masculinity: the particular ways of representing and using men's bodies. One of the sites where circuits of social embodiment become visible, they argue, are cultural symbols related to health, illness and 
medical treatment (Connell \& Messerschmidt, 2005). Cultural symbols in popular media - particularly in the area of health and care labour — contribute to the social construction of masculinity. An example of this is the figure of the "new man" that emerged during the 1970s under feminist claims of men getting more involved in nurturing and caring work, particularly in relation to parenthood (Beynon, 2002). However, other authors have argued that portrayals of the good father were hardly more than a dimension of postfeminist masculinity (Agirre, 2012). A decade later, partly driven by marketoriented media strategies, the "new man" evolved into a narcissistic model of consumerism where masculinity became eroticized, reified and hypermasculine (Beynon, 2002; Healey, 1994). Both models of the 'new man' the caring and the narcissistic - united in an undetermined and generalized "new man-ism" stood strong through the whole decade (Beynon, 2002). During the 1990s they were complemented by a "laddish" masculinity, a new kind of hedonistic, misogynous, rude, promiscuously heterosexual man, who is typically a sports fan and heavy drinker who does not hide his anti-feminist ideas (Gill, 2003; Edwards, 2003). The figures of the "new man" and the "new lad" currently co-exist in Western societies, the latter mainly being an ironic backlash against both the narcissistic and caring variants of the new man. At the same time, both figures enable the construction of masculinities that move in between these extreme positions. In this article we are especially interested in the caring part of the "new man" of the 1970s and how caring masculinities - excluding fatherhood - are constructed and articulated in particular instances of fiction film.

\section{Caring Masculinities and Feminist Care Theory}

So what could, would, or do these caring masculinities look like, considering that care work was until very recently considered as the "natural preserve of women alone" (Fine \& Glendinning, 2005, p. 602)? Karla Elliott proposes that caring masculinities can be seen as "masculine identities that exclude domination and embrace the affective, relational, emotional, and interdependent qualities of care identified by feminist theorists of care" (Elliott, 2015, p. 13 our emphasis). This path to embracing non-hegemonic qualities of care such as positive emotion, interdependence, and relationality has been identified by feminist theorists of care during the last four decades. Feminist 
care theory has been concerned with dismantling the assumption of natural caring characteristics of women with different arguments. One of them is the argument that care and care work is an inescapable part of human life, as something integral to human survival (Tronto, 1993; Kittay, 1999). Tronto (1993) introduced the concept of dependency in the discussion on care by stating that everyone will need care at some stage of their life (as a baby, when sick, when old etc...). Dependency therefore does not mean that you are inferior or in a position of inequality, as everyone will be dependent at some point. This vision was later developed by Eva Kittay (1999) who added that "the work of caring for dependents [...] must be done by someone" (Kittay 1999, p. 16).

With Niall Hanlon (2012), and his seminal empirical study on men's caring in the home in Ireland, we believe that care is central to human relationships and care labour is therefore a significant gender equality issue. Kittay's (1999) initial argument that a caregiving relationship should be a relationship of equality, where dependency is not stigmatized, inevitably leads to gender equality and the rejection of domination by men. Kittay argues that "dependence implies power relationships" (Kittay, 2011, p. 53), including power relationships in terms of gender. We argue that there is a place for men in caregiving work provided that men reject the hegemonic masculinity features that exclude the possibility of caring without having to constantly prove themselves as men (Coston \& Kimmel, 2012). Following hooks (2004a), in a "non-dominator culture" male caregivers would have to become disloyal to patriarchal masculinity so that new masculinities can develop that are not associated with violence or the will to dominate.

Another way of deconstructing the "natural" female ability to care is the concept of relational responsibility proposed by Maher, Wright and Tanner (2013): responsibilities in a caregiving relationship are negotiated in terms of the needs, desires, tastes and individualities of the person receiving care, regardless of gender. In the same direction, Held (2006) introduced interdependence as one way of looking at care in which mutuality, reciprocity and intertwining of interests are central. This reciprocity is not necessarily understood as direct reciprocity between two individuals - as in you cared for me so now I care for you —, but as Kittay (1999) suggested should be opened up to a wider societal concept of "connected-based" reciprocity where we all have the obligation to care for the dependent at some point. The concept of 
reciprocity will prove useful for this study as we want to look at the different relationships between the characters of the films: a professional, remunerated relationship (Intouchables), a son-father relationship (Nebraska) and reciprocity between spouses (Still Mine).

Concerning the positive features of care such as positive emotion, gratification and complicity between caregiver and care-receiver, these are not generally seen as something experienced by or characteristic for men. As Mike Donaldson observed in the 90s with regard to hegemonic masculinities and fatherhood, "nurturant and care-giving behaviour is simply not manly" (1993, p. 650). Likewise, Seidler (2006) found that intimacy is often experienced by men as threatening to male identity. Hanlon (2012), in one of the most extensive accounts of caring masculinities so far, found that men who did care work in Ireland reported feelings of shame when they could not live up to the ideals of hegemonic masculinity, while also acknowledging their positive experience when caring for someone.

Interest lies, then, in exploring how the male caregivers in Intouchables, Nebraska and Still Mine are portrayed in terms of rejection of domination and embracing positive experiences. We will argue that humour, complicity, outdoor action and preserving the care-receiver's dignity are some of those positive features of caring masculinities in these films.

\section{Notes on Methods}

The findings of this study are based on close readings of three acclaimed fiction films of the last decade. The main selection criteria were that the film should depict a male protagonist taking care of another person, and whose caregiving task was the main theme of the film. We selected Intouchables/The Untouchables (directed by Nakache and Toledano 2011), Still Mine (directed by McGowan 2012) and Nebraska (directed by Payne 2013). In the based-on-a-true-story French film Intouchables the young Driss, a black lower class ex-convict, is hired against all odds by tetraplegic Philippe, a rich Parisian aristocrat, to take care of him. Eventually they become friends, and while the young Driss will help Philippe to start feeling strong emotions again and a will to live, he is introduced to high culture and Philippe's arty entourage and snobbish way of life. In Still Mine, a Canadian film also based on true facts, the main character is Craig, a retired man who takes care of his 
wife Irene who has Alzheimer's disease. They live in a rural area and their main purpose is to fight the bureaucracy preventing them from building a new house that suits Irene's health needs - and emotional drives. Finally, in the American film Nebraska, David accompanies his dementia suffering father Woody on a trip through the inner states of the US to collect a (fake) million dollar prize and, at the same time, restore his dignity. In this film, the caregiving itself is less explicit than in the other two, but the attitudes of the son in accompanying his old father on his trip is clearly a caring activity within our broader understanding of care-taking. These three movies have been selected as outstanding examples of mainstream box office hits with a caregiving activity performed by a male protagonist. The three films, while very different in terms of budget and production, were all internationally distributed and have thus had an impact on the representation of masculinities in many countries.

Our close reading method inferred the features of the figure of the 'caring man' by looking at the text and the (cultural) context. We have taken the concept of figure from Gill's media analysis (2008), defining figure as the way in which particular bodies are represented in an excessive, distorted and/or caricatured way. Based on the fact that in all three films the figure of 'new man' is re-discovered and given new dimensions, we analyzed the figures of the caring masculinities portrayed in these three films by posing the following questions to characters and plot:

1. Which figures of masculinity are present in this film? Do these respond to hegemonic masculinity, and to which degree?

2. Which models/portrayals of care are identified, and how are these embodied by the male caregivers in the film?

Finally, we contrasted the construction of these figures with the theoretical notions developed above on (hegemonic) masculinity and feminist care theory. The close readings of the films were performed by all three researchers separately, and coded according to this mixed induction/deduction method. In the final phase, the researchers discussed and interpreted findings. Below, we develop our results in three different sections: the rejection of domination by these male characters, the representation of care-taking as a positive experience and, finally, the specific features of caring men and their 
caregiving tasks: developing humour and complicity, sharing outdoor activities and focusing on the dignity of the care-receiver.

\section{Rejection of Domination}

In all three films the male caregivers Driss, David and Craig are portrayed in daily caregiving activities such as personal hygiene and assistance in case of injury or pain: the almost maternal caring gestures performed by Driss (Intouchables) when Philippe is having a pain crisis; by David (Nebraska) after Woody has fainted and lies bleeding on the floor; and by Craig (Still Mine) after his wife has fallen down the stairs and is unconscious, are identical. Caring gestures are portrayed in all three films as surging naturally from the characters: it happens without them facing any conflict or dilemma.

In all three films we have identified some kind of "rejection of domination" (as defined above, see Elliott, 2015), at least with regards to the act of caring itself. In their role as caregivers, all three protagonists establish a horizontal and non-dominator relationship with the person they take care of. However, the model of masculinity presented in Intouchables - and to a lesser degree in Nebraska - is not devoid of a dominant attitude, especially towards women, and in some cases also entails suffering for not reaching the standards of hegemonic masculinity. In Still Mine, the rejection of forms of gender domination is more clearly observed, although some attributes of masculinity are still present in a compensatory way in non-caring tasks taken up by the protagonist.

In Still Mine, the caring process transforms Craig's masculinity, as he is determined to care for his wife Irene until the end. In the beginning of the film the character of Craig is an embodiment of hegemonic masculinity: he is brave, strong, tough, competitive with neighbours and psychologically stable, which is apparent from his continuous clashes with the administration and especially in the scene where he testifies before a court that accuses him of violating building laws, bringing a valuable baseball signed by two wellknown players with him. On the other hand, there is also the uncertainty and a relative fragility of ageing hanging over him, expressed early in the film when discussing death with his wife, and later on when he cries at a friend's funeral. But then again, he does not verbalize his fear. Despite his armoured 


\section{MCS - Masculinities and Social Change, 7(1) 91}

masculinity, Craig is a markedly domestic character: he establishes his identity around the idea of home, a space of intimate and autonomous relationships he clings to as an act of resistance to the inevitable process of dependence. The main objective of the character and the film is, in fact, the construction of a suitable house for Craig to take care of Irene and grow old together.

Concerning the relationship between the spouses, at first Craig refuses to assume the growing dependency of his wife, as he gets annoyed when her illness becomes visible. This asymmetry in their relationship is diluted throughout the course of the caring process, when Craig integrates his wife's disease as a part of the relationship and is able to respond tenderly to its manifestations. It is true that, in words of Kittay (2011), the dependency relationship initially establishes an unequal distribution of power, but what is interesting in this film is how Craig deliberately uses this 'power' to try to establish a lifestyle that corresponds to the wishes and needs of his wife. This is in sharp contrast with the position of the couple's children, who want to force Irene into a specialized institution, assuming she no longer has agency to decide her own destiny. Undoubtedly, the husband is the leading character and the centre of the action, and as such has more agency and presence on the screen than his wife, but unlike their children Craig accompanies and discusses everything with Irene. In fact, much of the footage represents the conversations between them and expresses the fears and volitions of the couple. It is symbolically significant that at the end of the film Craig is willing to lose his valuable baseball, legacy of paternal filiation of his father, in order to ensure proper care for his wife, thus shedding off the baggage of masculinity in favour of intimacy and care without much fuss.

In Nebraska neither of the characters fit into the standards of hegemonic masculinity - which to some extent causes other men to humiliate them-, and there is no dominance of David, the caregiver, over his sick father Woody. However, the character of Woody, although blurred by his current financial and health condition and with a wife who mocks him, is presented as a stereotype of American masculinity: taciturn, grouchy, reckless, a drinker, man of bars and sports, and with a history of infidelity regarding his wife. In a way, the Leitmotiv of the film is Woody's intents to recover these symbols of his long-lost masculinity. In order to hold on to it, Woody does not admit the fiasco of his business, and he wants to own a property so that 


\section{Araüna, Tortajada \& Willem-Caring masculinities in film}

he can leave it in inheritance to his sons. He is obsessed by owning agricultural machinery that affirm his virility, such as a truck or a compressor. To achieve this, he starts a road trip with his son to collect a scam money prize. In the diegetic world of Nebraska, a very localized idea of hegemonic masculinity is represented: being able to stand up against danger and risk and being respected by other men. Thus, in one of the key scenes of the film, in which the neighbours of Woody's home town mock the father and his quixotic obsession with collecting the prize, the son stands up to them and does something that is antagonistic to his bland character: he punches the leader in the face. In this manifestation of hegemonic masculinity through the use of violence, the son recovers his dad's respect and this is a first moment of genuine connection between the two of them.

Regarding Intouchables, both Driss and Philippe show traits of hegemonic masculinity: they are both competitive, womanizers, and they love speeding on the highway. However, taking into account the multiple vectors of privilege (Coston \& Kimmel, 2012) and Connell's account of 'marginalized masculinities' (Connell, 1987), both characters are also located in marginal spaces of masculinity: Philippe as a disabled person and Driss in terms of race and class. Hence, the features of hegemonic masculinity performed by both characters, such as the objectification of women, can be interpreted as a compensatory resource to normalize their status of men. This strategy of hyper-masculinization is especially visible in the case of the caregiver, Driss, who manages conflicts by using violence, always takes the initiative, brags about taking advantage of the system, breaks traffic rules and (sexually) harasses one of the female employees at Philippe's house. The way he treats her is coherent with the way he talks about women on several occasions in the film, as objects to look at and have sex with. Driss's initial portrayal thus responds to some of the stereotypes of black masculinity as pointed out by hooks, such as aggressive and harassing sexuality (Hooks, 2004b).

Philippe, on the other hand, shows traits of a more classy masculinity with a high level of cultural capital: he is well-educated, used to be a successful, well-dressed professional with expensive outdoor hobbies and an exquisite taste for art. Philippe's attempts to reclaim some of these traits and above all his virility in dealing with women - from prostitutes to a platonic love is one of the driving forces behind the narrative of care in this film. 


\section{MCS - Masculinities and Social Change, 7(1) 93}

\section{Embracing Caregiving as a Positive Experience}

Driss, Craig and David voluntarily take up their role as carers. We have already discussed the caring gestures displayed by the three protagonists in the previous section. Despite the complexities and conflicts posed by the films with regard to taking care of a dependent person, the care process itself is presented in all three cases as a mainly positive experience, and places the carers in a valuable and enriching personal relationship with their subject. In Still Mine and Nebraska, care stems from a family relationship (spouses and father-son respectively), while in Intouchables it is a professional and remunerated service, although it will gradually lead to a deeper bond between Driss and Philippe. In the following sections we examine the characters of all three films in terms of interdependence (Held, 2006) and reciprocity (Kittay, 1999), considered by these authors as part of the positive experiences of caregiving.

In Still Mine interdependence is based on traditional values and the principle of mutuality and direct reciprocity: when asked by his daughter about cooking and caring for his wife Irene, Craig says that "she would have done the same thing" and "she has always cooked for me, now it's my turn". As the story evolves Craig performs more domestic tasks such as cleaning or washing. The film emphasizes the dialogical evolution in the couple's relationship and in the last scene we see how Irene cuts her husband's hair and caresses his face, as an iconic image of how both partners of the couple pamper each other. Likewise, this relationship is embedded in a broader context of networks of solidarity either within the family or in the community: for example, the neighbour who Craig has been lending money to saves him from the court's allegations by telling journalists about this magnificent love story. In Nebraska this direct reciprocity is based on David's naturalized idea that children should take care of their parents: 'he took care of me when I was a kid'. At the moment he decides to join Woody on a road trip to collect his prize in Lincoln, Nebraska, David's life is on a turning point: he has lost his job because of his lack of assertiveness and his girlfriend has left him and moved out. When he initially says that he cannot just drop everything and drive to Nebraska, his father pressures him, quite sarcastically: "Oh. What else you got going on?" The asymmetrical relationship between father and son gradually reverses, and in the end David is acting as the responsible one, 
exhibiting more authority than his dad ever had from the beginning. Despite this evolution of David becoming firmer, there are no explicit moments where his dad is capable of returning some tenderness, understanding or empathy to his son. In this sense this film portrays a more unbalanced relationship between carer and care-receiver, at least with regard to what characters are willing to give. Although it is true that David has the opportunity to enjoy the trip with his father and evolve during the journey, turning the caring process into something positive for him, this evolution is undeniably tied to codes of masculinity. David's manifestation of hegemonic masculinity - in terms of violence and competitiveness - comes to a climax when he hits a bully in a bar.

In Intouchables interdependence takes on a different notion as Driss and Philippe are not related to each other. Instead of direct reciprocity, there is a mutual interest in the relationship based on several elements: initially, it is about a bureaucratic issue (Driss needs a certificate that he has applied for a job in order to get unemployment benefits), then about money and status (as Driss is hired by Philippe and gets his own luxury suite in the mansion), but gradually the remunerated relationship evolves towards a deep friendship, where both members are equal and complementary. Driss helps Philippe to get out of the house, to go places, having fun; Philippe in turn provides Driss with a fast car, luxury and status, and introduces him into the world of modern art-even if both of them will eventually mock Philippe's snobbish environment. These specific characteristics of the relationship between Driss and Philippe are described by the latter in his best-selling memories ${ }^{1}$.

\section{Qualities of the Caring Man}

Additionally, to Driss, David and Craig's rejection of domination and their positive experiences of reciprocity, our caring men also draw on other specific notions of care which oppose the 'traditional' or institutionalized image of care labour as dull and cumbersome, and the caregiver as over-worried and patronizing: they add humour, complicity and outdoor action to their caregiving practices and dignify the person they care for. 


\section{Humour and Complicity}

The ability to use and maintain a sense of humour in critical situations - in contrast to being over-worried, often understood as typically feminine caregiving - is something highlighted as positive in the caregiving styles of the main characters of these films, particularly in Nebraska and Intouchables. This sense of humour is embodied in the published memories of the real-life Philippe Di Borgo, who wanted the Intouchables film adaptation to be a comedy $^{2}$. Laughing becomes an antidote for pity, the latter being a category rejected by Philippe all along in the movie and asserted the real Philippe in an interview: "He didn't feel sorry for me - he was irreverent, cheeky and had an outrageous sense of humour. I suddenly found I was enjoying life again, feeling like I didn't know what was coming next" 3 . In an interview in The Guardian the directors underscore that the humour in the film is an essential feature of the main characters' relationship: "We just tried to make love with this story ... the humour saves these two people. It's a kind of British humour. The British can joke about everything, even misery." ${ }^{4}$ In Nebraska the sense of humour is implemented from the enunciating position in the film, a third person who - in complicity with the spectator - smiles at the absurdity of the situation in which the characters find themselves. Once David and his father Woody consolidate their complicity, they will be able to solve the particular needs of caregiving in their given situation (a father with dementia who wanders off in pursuit of a million dollar prize). In Still Mine, humour operates as a distancing mechanism from trauma and fear, as embodied in Craig's ironic responses to ageing and death. This sense of humour is precisely what will allow Craig to continue with his role of caregiver, and despite adversity he will be able to identify as superfluous the other challenges impeding his commitment to take care of his wife. The sense of humour, moreover, presents itself as a response to the fear of the other and, therefore, as an act of generosity and complicity in a shared adventure.

\section{Outdoor Action}

The caregiving processes in these films take place outside the domestic space rather than inside, in different ways and degrees. The clearest example of 


\section{Araüna, Tortajada \& Willem - Caring masculinities in film}

outdoor action is Nebraska, where the care-taking activity itself is a transformative road trip, an adventure in which father and son get to know each other more deeply and recover - or at least perform - their masculinity in a variety of situations and encounters with other people. It is Woody's wife who opposes their adventure and considers that they should remain at home, which both men discard as they clearly want to experience this more enriching adventure. In this case, a 'masculine' trait (driving, exploration, adventure) is put into contrast with a more conservative and repressing notion of feminine care. In Intouchables, the opening scene pictures Driss and Philippe speeding through the streets of Paris, and mocking the road police. As the story evolves, Philippe's character development will finally lead him to leave his comfort zone (as well as his mansion), start practicing paragliding again and finally meet the woman who he has been writing. In both films the distinctive elements are cars, roads and driving.

Although Craig also takes out his wife for small trips to town, Still Mine makes for a different case, as the central element of the film is the house. Craig's building activities can be seen both as a representation of an outdoor activity (the act of building a house) and as an element of the domestic sphere (the house being prepared for a future intimate life together). One might wonder if there is any connection between this domesticity of Craig's activity and the fact that the care-receiver is a woman in this case, unlike in the other films. From this perspective, the characters who take into account their subjects' needs and desires (Maher, Wright \& Tanner, 2013), tend to leave the home with male care-receivers and stay at home more often with female carereceivers. In any case, regardless of the care-receiver, the movie puts great emphasis on Craig's outdoor activities as part of his aim not to feel old and his public life among the villagers.

\section{Preserving the Care-Receiver's Dignity}

The portrayals of caregiving in these films -with humour, complicity and outdoor action- are not so much about avoiding health risks, or even comforting the person taken care of, but rather about granting or returning them some dignity despite their incapacity or dependency. To preserve the care-receiver's dignity seems to be the motive of the care activity in all three films, and also their main message. The main aim of the caregivers, as derived from 
our analysis in previous sections, is to ensure the dignity of the care-receivers by respecting their needs and desires, and providing spaces for self-realization. In Still Mine, for example, Craig struggles against bureaucracy, as well as against his own children, in order to avoid his wife to be placed in an institution where she would not have liked to stay. If a new home has to be built in order to stay together, then this house will be built no matter what. What is important here is the fact that Craig's actions are driven by his wife's desires and needs; her dignity.

In the final scene of Nebraska, Woody will show off his new truck in front of the men who humiliated him. What ultimately heals him is this social reparation of his status, as well as purchasing something for his sons to inherit. It will take some time until David comes to understand his dad's need, but when he finally does he is a complice to preserve Woody's dignity by allowing him to take revenge. A clear and explicit example of dignified care in Intouchables is Philippe's rejection of previous caregivers by hiring a badbehaved but lively Driss: he expects to be treated as a real person instead of being pitied and patronized. When asked by a friend why he has hired an excon to take care of him, Philippe answers: "He doesn't see my disability. He forgets. He sometimes even hands me the phone." Soon, Driss will fulfill not only his expectations as a caregiver but starts focussing his efforts on getting Philippe 'out there' again.

In an interview with The Telegraph, the real-life Philippe (Pozzo di Borgo) points out:

He treated me like I needed to be treated in the tough times ahead, partly because of my condition but also because my wife was dying of cancer [she died three years after his accident]. I needed to be back on track. Pity is the last thing you need. Pity is hopeless. Pity is what someone gives you because he is afraid to take care of you. I didn't need that. But compassion I don't need also. It comes from Latin and means 'suffering with'. I don't want you to be suffering with me. I need consolation, which in Latin means keeping me as a whole person, respecting me as I am. ${ }^{5}$

We can say that the caring masculinities in the three films all have this one thing in common: the carer respects the care-receiver as a "whole person" instead of pitying them. All three carers firmly reject pity as a caring strategy, 


\section{Araüna, Tortajada \& Willem - Caring masculinities in film}

each in their own way: Driss by not sparing Philippe regarding his condition - even joking about it; David by not treating his father as a helpless child; Craig by respecting his wife's desires and wishes, including her sexual ones.

\section{Conclusions}

Models of non-hegemonic masculinities are emerging in media representations through fiction film narratives about caregiving. Men's ambiguous relationship with caring work becomes visible on the screen within a historical context where "care-free" and "nurturing" experiences for men are competing for attention (Hanlon, 2012). Indeed, care work is becoming more visible in the public sphere of Western societies as life expectancy gets higher and caregiving is moving out of the domestic sphere (Comas d'Argemir, 2016), and this is contributing to more diverse portrayals of care in media and popular culture. Thus, this new focus on care constructs masculinities associated with it, and at the same time discourses of masculinity redefine notions of care. The value of care was part of hegemonic masculinity in the 70s, with the emergence of the "nurturer" and "caring man" but these figures disappeared later in favour of more hedonistic models and "new laddism" (Beynon, 2002; Gill, 2003; Edwards, 2003). However, in the same way that masculinities are multiple and diverse, the male caregivers appearing in Intouchables, Nebraska and Still Mine are so too: each film constructs a different configuration of the traits of caring masculinities. Care understood as a part of Driss, Craig and David's masculinity confers a model that rejects patronizing and overprotecting the care-receiver and instead emphasizes dignity and social identity through humour, complicity, and activities outside the domestic space. Instead of a situation of assistance and protection, the caregiving process is thus presented as a vital outbreak, especially in Nebraska (road trip) and Intouchables (recovering the pleasures of life). In Mine Still we find in Craig the same kind of spirit to cope with aging and degenerative disease, although the domestic space here is still important.

We should, however, be wary of overly positive portrayals of caregiving by men in these films as being fun - involving humour, friendship, adventure and outdoor action - as opposed to a generally more negative portrayal of women carers or institutionalized caregiving as oppressive, tedious and patronizing. It remains to be seen if these constructions of fun and positive 
experience will convince "care-free" men (Hanlon, 2011) to get more involved in care work. Additionally, this involvement would not necessarily mean that other aspects of domination linked to hegemonic masculinity, currently deeply embedded in gender relations, would be neutralized. In Intouchables we see a clear example in the way Driss and Philippe talk about women, and how Driss - the vital, ideal caregiver to Philippe - approaches women as sex objects.

In summary, we cannot and should not assume that an evolution towards more and more positive involvement of men in caregiving activities will necessarily lead men to becoming disloyal to patriarchal masculinity (Hooks, 2004a). But from the above analysis of fiction film it seems clear that caring masculinities can be compatible with other masculinities, including hegemonic masculinity. At a time where care-free and nurturing experiences for men are competing for influence, strategies such as humour, complicity with the care-receiver, dignifying practices and outdoor action can solve the tension, both for male and female carers. These positively framed features of caring masculinities can encourage men to uptake care work and ultimately opens new spaces for defining care as a gender neutral activity.

\section{Notes}

1 This research was funded by Obra Social "La Caixa" (Recercaixa) and the Asociación Catalana de Universidades Públicas (2014ACUP00045)

${ }^{2}$ Pozzo di Borgo, P.. (2012). Intocable. Barcelona: Anagrama.

3 "The directors and actors visited Di Borgo, who insisted that they made a comedy and went on to act as the film's adviser". In: Alberge, Dalia (2012): Untouchable: how did a French comedy about disability become a global hit?

https://www.theguardian.com/film/2012/sep/06/untouchable-french-comedy-disability

4 Farndale, Nigel (2012): Untouchable: the true story that inspired a box office hit http://www.telegraph.co.uk/culture/9509665/Untouchable-the-true-story-that-inspired-a----box-office-hit.html

${ }^{5}$ Declarations by Eric McGowan in: Alberge, Dalia (2012): Untouchable: how did a French comedy about disability become a global hit? https://www.theguardian.com/film/2012/sep/06/untouchable-french-comedy-disability

6 http://www.telegraph.co.uk/culture/9509665/Untouchable-the-true-story-that-inspired-a----box-office-hit.html 
100 Araüna, Tortajada \& Willem - Caring masculinities in film

\section{References}

Agirre, K. (2012). 'Whenever a man takes you to lunch around here': Tracing post-feminist sensibility in Mad Men. Catalan Journal of Communication and Cultural Studies, 4(2), 155-70. doi:

10.1386/cjcs.4.2.155_1

Berger, A., \& Yerxa, R. (Producers), \& Payne, A. (Director). (2013). Nebraska [Motion Picture]. Madrid: Vértigo.

Beynon, J. (2002). Masculinities and Culture. Buckingham: Open University Press.

Carrigan, T. R., Connell, R. W., \& Lee J. (1985). Toward a new sociology of masculinity. Theory and Society, 14(5), 551-604. doi: 10.1007/BF00160017

Connell, R. W. (1987). Gender and Power: Society, the Person and Sexual Politics. Cambridge: Polity Press.

Connell, R. W. (1990). An Iron Man: The Body and some contradictions of Hegemonic Masculinity. In M. A. Messner \& D. F. Sabo (eds.), Sport, Men and the Gender Order (pp. 83-95). Champaign, IL: Human Kinetics.

Connell, R. W. (1996). Teaching the Boys: New Research on Masculinity, and Gender Strategies for Schools. Teachers College Record, 98(2), 206-35. Retrieved from https://www.xyonline.net/sites/default/files/ Connell,\%20Teaching\%20the\%20Boys\%2096.pdf

Connell, R. W., \& Messerschmidt J. W. (2005). Hegemonic Masculinity: Rethinking the Concept. Gender \& Society, 19(6), 829-59. doi: $10.1177 / 0891243205278639$

Comas d'Argemir, D. (2016). Hombres cuidadores: Barreras de género y modelos emergentes. Psicoperspectivas, 15(3), 10-22. doi:

10.5027/psicoperspectivas-Vol15-Issue3-fulltext-750

Colero, J., Federgreen, A., Deverell, T., \& McGowan, M. (Producers) \& McGowan (Director). Still Mine [Motion Picture]. (2012). Los Angeles: 20th. Century Fox Home Entertainment.

Coston, B. M., \& Kimmel, M. (2012). Seeing Privilege Where It Isn't. Marginalized Masculinities and the Intersectionality of Privilege. Journal of Social Issues, 68(1), 97-111. doi: 10.1111/j.15404560.2011.01738.x 
Donaldson, M. (1993). What Is Hegemonic Masculinity? Theory and Society, 22(5), 643-657. doi: 10.1007/BF00993540

Duval N., Zeitoun L., \& Zenou, Y. (Producers), \& Nakache, O., \& Toledano, E. (Directors). (2011). Intouchables [Motion Picture]. France: Gaumont/TF1 Video.

Edwards, T. (2003). Sex, booze and fags: masculinity, style and men's magazines. The Sociological Review, 51 (S1), 132-46. doi:

10.1111/j.1467-954X.2003.tb03607.x

Elliott, K. (2015). Caring Masculinities: Theorizing an Emerging Concept. Men and Masculinities, 19(3), 1-20. doi:

10.1177/1097184X15576203

Fine, M., \& Glendinning, C. (2005). Dependence, Independence or Interdependence?? Revisiting the concepts of 'Care' and 'Dependency'. Ageing \& Society, 25(4), 601-22. doi: 10.1017/S0144686X05003600

Gill, R. (2003). Power and the production of subjects: a genealogy of the New Man and the New Lad. The Sociological Review, 51(1), 34-56. doi: 10.1111/j.1467-954X.2003.tb03602.x

Gill, R. (2008). Empowerment/Sexism: Figuring Female sexual Agency in Contemporary Advertising. Feminism and Psychology, 18(1), 35-60. doi: 10.1177/0959353507084950

Hanke, R. (1998). Theorizing Masculinity With/In the Media. Communication Theory, 8(2), 183-201. doi: 10.1111/j.1468-2885.1998.tb00217.x

Hanlon, N. (2012). Masculinities, care and equality: identity and nurture in men's lives. London: Palgrave Macmillan.

Healey, M. (1994). The mark of a man: masculine identities and the art of macho drag Critical Quarterly, 36(1), 86-93. doi: 10.1111/j.14678705.1994.tb01016.x

Held, V. (2006). The Ethics of Care. Personal, Political and Global. New York: Oxford University Press.

hooks, B. (2004a). The Will to Change: Men, Masculinity and Love. New York: Atria Books.

hooks, B. (2004b). We real cool. Black men and masculinity. New York: Routledge.

Kimmel, M. S. (1993). Invisible Masculinity. Society, 30(6), 28-35. doi: 10.1007/BF02700272 
Kittay, E. F. (1999). Love's Labor: Essays on Women, Equality, and Dependency. New York: Routledge.

Kittay, E. F. (2011). The Ethics of Care, Dependence and Disability. Ratio Juris , 24(1), 49-58. doi: 10.1111/j.1467-9337.2010.00473.x

Maher, J., Wright, J., \& Tanner, C. (2013). Responsibility and Resistance. Women Negotiating the Nourishment of Children. Families, Relationships and Societies, 2(2), 193-209. doi:

10.1332/204674313X667399

Seidler, V. (2006). Young Men and Masculinities: Global Cultures and Intimate Lives. London: Zed Books.

Tronto, J. C. (1993). Moral Boundaries. A Political Argument for an Ethic of Care. New York: Routledge.

Núria Araüna, Lecturer, Communication Studies Department, Universitat Rovira i Virgili, Spain.

Iolanda Tortajada, Associate Professor, Communication Studies Department, Universitat Rovira i Virgili, Spain.

Cilia Willem, Visting Scholar, Communication Studies Department, Universitat Rovira i Virgili, Spain.

Contact Address: Direct correspondence to Cilia Willem, Communication Studies Department, Av. Catalunya, 3543002 - Tarragona, Spain, email: cilia.willem@urv.cat 